\title{
Diabetic retinopathy with normal glucose tolerance
}

\author{
A. D. B. HARROWER AND B. F. CLARKE \\ From the Diabetic and Dietetic Outpatient Department, Royal Infirmary, Edinburgh
}

Various histological (Siperstein, Norton, Unger, and Madison, 1966; Siperstein, Unger, and Madison, 1968; Siperstein, Unger, and Madison, 1970) biochemical (Camerini-Davalos and Cole, 1970; Goto, Toyota, Takaku, Sato, and Irie, 1970), growth hormone (Soeldner, Sönksen, Gleason, and Boden, 1971) and insulin secretory (Cerasi and Luft, 1967) abnormalities have been reported in 'pre-diabetics' who, by definition, have normal standard glucose tolerance. Despite this, however, there have been only a few reports of typical diabetic complications, particularly retinal (Collens, Silverstein, and Dobkin, 1959; Levine, 196I; Linner, Svandborg, and Zelander, 1965; Johansen, 1969; Siperstein, 1969) or renal (Collens and others, 1959; Linner and others, 1965) angiopathy occurring in such subjects.

A patient who presented with typical diabetic exudative and proliferative retinopathy, but had normal standard glucose tolerance, is described. It was concluded that in such cases the diabetes was probably latent, the retinopathy being discovered during a period of natural or induced remission when glucose tolerance had reverted to normal.

\section{Case report}

A 62-year-old woman was referred by her family doctor because of visual impairment which had developed gradually during the previous year. There had been no previous hospital admissions and apart from her presenting complaint she was asymptomatic. She had been obese since her teens, had not been known to be hypertensive, nor at any time in the past had she noted symptoms suggestive of diabetes mellitus. An older sister aged $7 \mathrm{I}$ years was a known maturity-onset diabetic attending the same clinic; she had been registered blind as a result of progressive exudative and proliferative diabetic retinopathy which had been present at diagnosis ro years previously.

On examination, the patient was markedly obese, weighing $86.5 \mathrm{~kg}$ (standard weight $6 \mathrm{r} \mathrm{kg}$ ). She was hypertensive, with blood pressure $190 / 1$ ro $\mathrm{mmHg}$, but her general physical examination was otherwise unremarkable. The visual acuity was reduced to $6 / 18$ in the

Address for reprints: A. D. B. Harrower, MRCP, Diabetic and Dietetic Outpatient Department, Royal Infirmary, Edinburgh right eye and $6 / 36$ in the left. Ophthalmoscopy revealed features characteristic of diabetic retinopathy with scattered microaneurysms and small discrete round 'blob' haemorrhages (particularly in the posterior polar regions of both retinae) and extensive clusters of yellowish, deep, hard exudates in the macular and perimacular regions. In addition, there was vitreous haze with a few small areas of neovascularization along the superior and inferior temporal vessels in the right eye and, in the left, a few areas of early neovascularization in relation to the superior temporal veins. There was also mild arterio-venous 'nipping' and a few superficial linear haemorrhages compatible with the hypertension. Unfortunately, because of vitreous haze it was not possible to take satisfactory photographs.

Laboratory investigations showed a normal two-hour postprandial blood glucose of $4 \cdot \mathrm{I} \mathrm{mmol} / 1(74 \mathrm{mg} / \mathrm{I} 00 \mathrm{ml})$ and full blood investigation-including haematology, blood urea, electrolytes, and uric acid-were all normal. Urine microscopy was normal and renal function satisfactory, there being no proteinuria, the creatinine clearances were 68 and $115 \mathrm{ml} / \mathrm{min}$ and the intravenouspyelogram was normal. Chest radiology showed slight cardiac enlargement affecting the left ventricle, but the electrocardiogram was normal. Urinary vanillyl mandelic acid was normal and the urinary 17-hydroxycorticosteroid excretion was $20 \mathrm{mmol} /$ day. Total plasma proteins were $73 \mathrm{~g} / \mathrm{l}$, albumin $40 \mathrm{~g} / 1$ with a normal electrophoretic pattern. Immunoelectrophoresis of the globulins was normal, and tests for antinuclear factor were negative. Fasting cholesterol was $7 \mathrm{mmol} / \mathrm{l}$, triglycerides $147 \mathrm{mmol} / 1$, and free fatty acids $1050 \mathrm{mmol} / 1$; a full clotting screen was normal. The standard oral glucose tolerance test, using a $5 \circ \mathrm{g}$ glucose load, which was repeated after an interval of seven days were both normal apart from a slight increase in the one-hour blood glucose value in the second test (Table I). Intravenous tolbutamide (Unger and Madison, 1958), and cortisone augmented glucose tolerance tests (Fajans and Conn, I954) were likewise normal (Table I).

A renal biopsy showed, on light microscopy, hyaline changes in the arterioles compatible with hypertension, but, unfortunately the tissue obtained was inadequate for a satisfactory assessment of diabetes.

The hypertension was controlled with debrisoquine $45 \mathrm{mg}$ daily and treatment was begun with clofibrate, $2.0 \mathrm{~g}$ daily, for the exudative element of the retinopathy (Duncan, Cullen, Ireland, Nolan, Clarke, and Oliver, 1968; Cullen, Town, and Campbell, 1974). During the subsequent three years there were vitreous haemorrhages in both eyes, and three years later the patient's visual acuity was reduced to counting fingers in the 
Table I Blood glucose mmol/l $(\mathrm{mg} / \mathrm{I} 00 \mathrm{ml})$ during tolerance tests of oral glucose, cortisone-augmented glucose, and tolbutamide

\begin{tabular}{|c|c|c|c|c|c|c|c|}
\hline $\begin{array}{l}\text { Oral glucose tolerance test } \\
(\mathrm{mmol} / \mathrm{l}(\mathrm{mg} / \mathrm{1} 00 \mathrm{ml}))\end{array}$ & $\begin{array}{l}\text { Time (hou } \\
F\end{array}$ & $\begin{array}{l}\text { r) } \\
\frac{1}{2}\end{array}$ & $\mathbf{I}$ & I $\frac{1}{2}$ & 2 & $2 \frac{1}{2}$ & 3 \\
\hline $\begin{array}{r}\text { Test } \mathbf{I} \\
2\end{array}$ & $\begin{array}{l}5 \cdot 0(90) \\
4 \cdot 9(88)\end{array}$ & $\begin{array}{l}9 \cdot 7(175) \\
8 \cdot 4(152)\end{array}$ & $\begin{array}{r}7 \cdot 7(138) \\
11 \cdot 4(206)\end{array}$ & $\begin{array}{l}3 \cdot 8(68) \\
8 \cdot I(146)\end{array}$ & $\begin{array}{l}2 \cdot 7(48) \\
5 \cdot 3(96)\end{array}$ & - & $-\overline{2 \cdot 7}(48)$ \\
\hline \multicolumn{8}{|l|}{$\begin{array}{l}\text { Cortisone-augmented glucose } \\
\quad \text { tolerance test }\end{array}$} \\
\hline $\begin{array}{r}\text { Test } \mathbf{I} \\
2\end{array}$ & $\begin{array}{l}5 \cdot 9(\text { I } 06) \\
6 \cdot 4\left(\begin{array}{ll}1 & 1\end{array}\right)\end{array}$ & $\begin{array}{l}\text { I I } 3(203) \\
12 \cdot 5(225)\end{array}$ & $\begin{array}{l}\text { I0.8 (194) } \\
\text { I I. I }(200)\end{array}$ & $\begin{array}{l}7 \cdot 7(138) \\
5 \cdot 1(92)\end{array}$ & $\begin{array}{l}4 \cdot 7(85) \\
5 \cdot 1(92)\end{array}$ & $\frac{4 \cdot 0}{-}(72)$ & $\begin{array}{l}2 \cdot 7(48) \\
-\end{array}$ \\
\hline \multirow[t]{2}{*}{ Tolbutamide tolerance test } & \multicolumn{7}{|c|}{ Time (minutes) } \\
\hline & $F$ & 20 & 30 & & & & \\
\hline \multirow{2}{*}{$\begin{array}{l}\text { Percentage decrease in blood } \\
\text { glucose }\end{array}$} & $5 \cdot 0(90)$ & $3.6(65)$ & $3 \cdot 1(55)$ & & & & \\
\hline & & 28 & 38 & & & & \\
\hline
\end{tabular}

right eye but remained at $6 / 36$ in the left despite two further vitreous haemorrhages. The Figure shows the current retinal appearances in the right eye with microaneurysms, haemorrhages, extensive hard exudates, and fibrosis. There had been a further vitreous haemorrhage in the left eye making photography impossible. The standing blood pressure is $200 / 100-180 / 90 \mathrm{mmHg}$ and her weight has decreased by $12 \mathrm{~kg}$. Random fasting and postprandial blood glucose values have been checked frequently and have remained well within the normal limits (range 3.6-5.8 mmol/l) (65-104 mg// $00 \mathrm{ml}$ ) during this period and a repeated cortisone glucose tolerance test was similar to that obtained originally (Table I).

\section{Discussion}

There is a paucity of reports of typical diabetic retinopathy in patients with normal glucose tolerance (Table II) which might be expected to occur more commonly if biochemical and histological abnormalities precede glucose intolerance as has been frequently observed (Siperstein and others, 1966, 1968, 1970; Cerasi and Luft, 1967; Camerini-Davalos and Cole, 1970; Goto and others, 1970; Soeldner and others, 1971).

Typical diabetic retinopathy at the time of diagnosis is, however, well recognized and has been variously reported as occurring in 4 to 15 per cent of patients (Waite and Beatham, 1935; Lawrence, I95 I ; Aarseth, 1953; Lundbaek, 1955; Kornerup, 1958; Pyke and Roberts, 1959; Soler, Fitzgerald, Malins, and Summers, 1969). In such cases the diabetes has probably been long standing and undiagnosed because of the mildness or absence of symptoms. Indeed, it has been calculated that for persons diagnosed over the age of 50 years, the mean length of time between the appearance of impaired carbohydrate tolerance and diagnosis is at least 10 years (Anderson, 1966).

There have been reports of minimal capillary basement membrane changes in various tissues such as ear lobe (Camerini-Davalos, 1965) and muscle (Siperstein and others, 1966, 1968, 1970) in 'pre-diabetics'. The demonstration of impaired insulin release in the close relatives of diabetics who have normal standard glucose tolerance (Cerasi and Luft, 1967), suggests that biochemical abnormalities may be present for some time before the development of overt diabetes and it is possible that the basement membrane changes are secondary to these. However, Bloodworth, Engerman, Camerini-Davalos, and Powers (1970) also using thigh muscle biopsies found no difference between the capillary basement membrane thicknesses in 'pre-diabetics' and their controls. Østerby (1970, 1972) failed to demonstrate significant basement membrane thickening in glomerular capillaries from recently diagnosed young diabetics, in whom the date of onset of diabetes could accurately be obtained. By studying successive renal biopsies during the next $2 \frac{1}{2}$ years, however, she showed a progressive increase in basement membrane thickness.

The patient we describe had a retinopathy which showed the typical combination and distribution of features characteristic of diabetes and with no evidence of veno-occlusive disease, hyperviscosity syndromes, retinal vasculopathies, or other conditions known to produce changes which may resemble diabetic retinopathy. The fact that a sister, with confirmed diabetes, had similar retinal changes at diagnosis may indicate an enhanced familial predisposition to diabetic retinopathy. In such cases the patients are probably latent diabetics, 


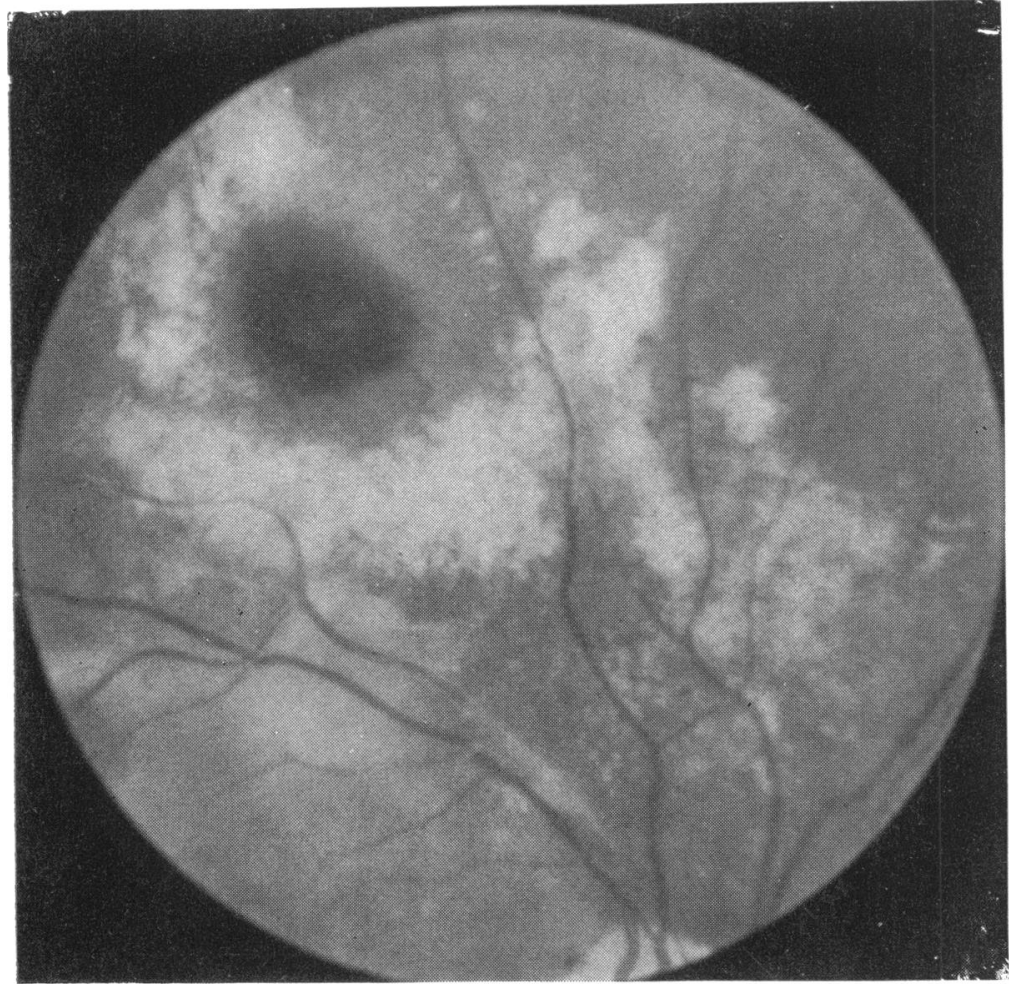

FIGURE Retinal photographs showing microaneurysms, haemorrhages, hard

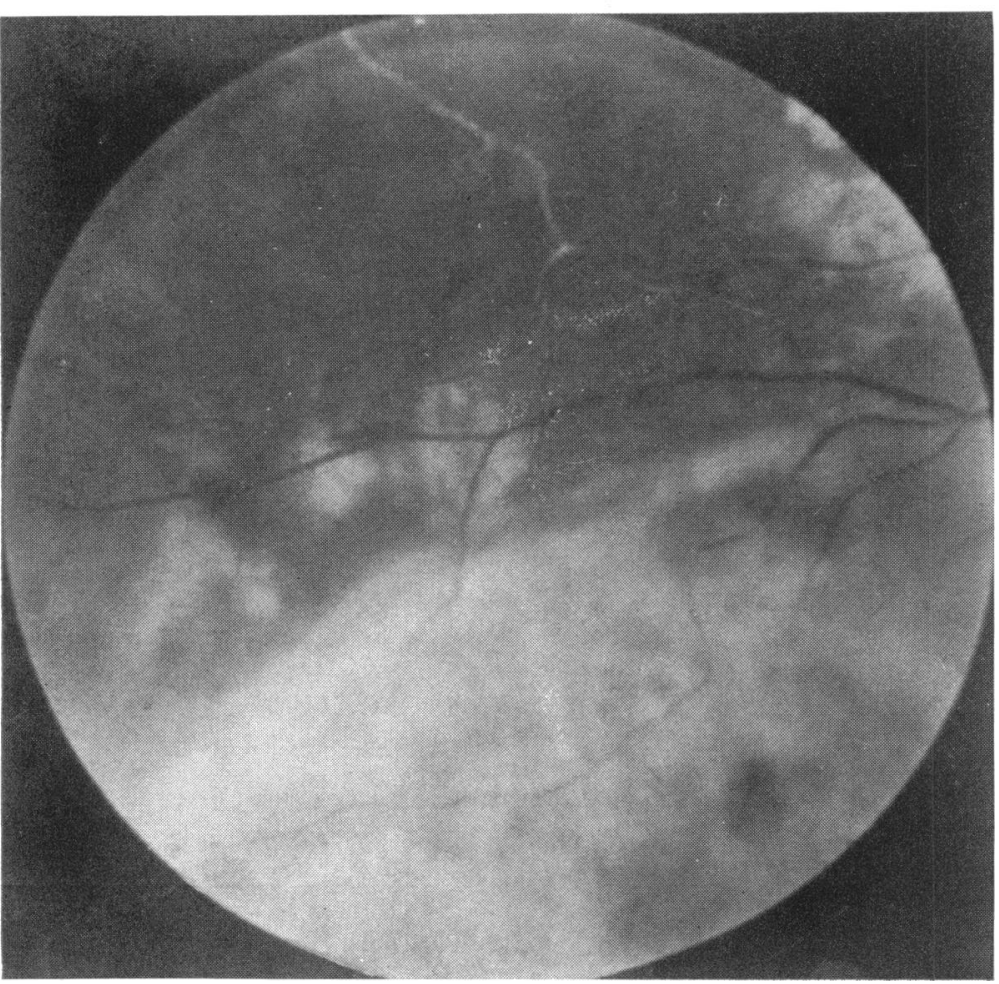
exudates, and fibrosis in the right eye 
Table II Reports of patients with normal glucose tolerance and typical diabetic retinopathy

\begin{tabular}{|c|c|c|c|c|c|c|}
\hline Reference & Sex & Age & $\begin{array}{l}\text { FH of } \\
\text { diabetes }\end{array}$ & $\begin{array}{l}\text { Retinal } \\
\text { appearance }\end{array}$ & $\begin{array}{l}\text { Other } \\
\text { angiopathy }\end{array}$ & Comments \\
\hline $\begin{array}{l}\text { Collens and others, } \\
\text { (1959) }\end{array}$ & Male & 42 & Yes & $\begin{array}{l}\text { Hard exudates, } \\
\text { microaneurysms, } \\
\text { haemorrhages }\end{array}$ & $\begin{array}{l}\text { Nodular } \\
\text { glomerulo- } \\
\text { sclerosis }\end{array}$ & $\begin{array}{l}\text { Obese. BP 180/100. } \\
\text { Diabetes diagnosed } \\
\text { I7 years before, but } \\
\text { GTT normal at time } \\
\text { of report. Abnormal } \\
\text { cortisone-augmented } \\
\text { GTT }\end{array}$ \\
\hline Levine ( $196 \mathrm{r}$ ) & Female & $\begin{array}{l}\text { 'early } \\
\text { forties' }\end{array}$ & $?$ & $\begin{array}{r}\text { Haemorrhages } \\
\text { proliferation }\end{array}$ & - & $\begin{array}{l}8 \mathrm{GTT} \pm \text { cortisol. } \\
\text { I abnormal }\end{array}$ \\
\hline $\begin{array}{l}\text { Linner and others, } \\
\text { (1965) }\end{array}$ & Female & 60 & Yes & $\begin{array}{l}\text { Microaneurysms } \\
\text { and dot } \\
\text { haemorrhage, } \\
\text { small hard } \\
\text { exudates }\end{array}$ & $\begin{array}{l}\text { No typical } \\
\text { diabetic } \\
\text { features on } \\
\text { renal biopsy }\end{array}$ & Normotensive \\
\hline Johansen (1969) & Male & 65 & Yes & $\begin{array}{l}\text { Microaneurysms } \\
\text { blob haemorrhages } \\
\text { and new vessels }\end{array}$ & $\begin{array}{l}\text { Diffuse } \\
\text { glomerulo- } \\
\text { sclerosis }\end{array}$ & $\begin{array}{l}\text { Diabetes diagnosed } 5 \\
\text { years before when } \\
\text { patient obese. GTT } \\
\text { normal, but became } \\
\text { abnormal after weight } \\
\text { gain }\end{array}$ \\
\hline Siperstein (1969) & Female & 54 & Yes & $\begin{array}{l}\text { Microaneurysms } \\
\text { and haemorrhages }\end{array}$ & $\begin{array}{l}\text { Quadriceps } \\
\text { muscle } \\
\text { biopsy } \\
\text { showed } \\
\text { increased } \\
\text { capillary } \\
\text { basement } \\
\text { membrane } \\
\text { thickness }\end{array}$ & $\begin{array}{l}\text { GTT normal on } \\
\text { repeated testing }\end{array}$ \\
\hline Present case & Female & 62 & Yes & $\begin{array}{l}\text { Microaneurysms and } \\
\text { blob haemorrhages } \\
\text { hard exudates, } \\
\text { new vessels }\end{array}$ & 一 & Obese. BP 190/I I0 \\
\hline
\end{tabular}

in whom retinopathy has been discovered during a period of natural or induced remission when standard glucose tolerance has reverted to normal. In the patient described genetic predisposition, the exacerbating effect of hypertension (Kornerup, 1958; Hollenhorst, 1962; Field, 1970), and insulin resistance caused by obesity may have been contributory factors.

\section{Summary}

A case is reported of a patient with typical diabetic retinopathy, but with normal glucose tolerance. Previously reported cases are reviewed and it is concluded that in such patients the diabetes is probably latent, the retinopathy being discovered during a period of natural or induced remission.

We are grateful to Dr L. J. P. Duncan for permission to study this present case and for his advice and criticism.

Dr J. F. Cullen was helpful in the assessment and management of the retinal changes and Dr D. Thomson and $\mathrm{Dr} J$. T. Ireland advised us on the renal biopsy material.

\section{References}

ANDERSON, T. W. (1966) Diabetes, 15, 160

AARSETH, S. (1953) Acta med. scand., suppl. 28I

Bloodworth, J. M. B., engerman, R. L., CAMerini-davalos, R. A., and Powers, K. L. (1970) 'Advances in

Metabolic Disorders', suppl. I. Early Diabetes, ed. R. A. Camerini-Davalos and H. S. Cole, p. 26r.

Academic Press, New York and London

Camerini-davalos, R. A. (1965) Med. Clin. N. Amer., 49, 865 
, and COle, H. S. (1970) 'Advances in Metabolic Disorders', suppl. I. Early Diabetes, ed. R. A. CameriniDavalos and H. S. Cole, p. 32 r. Academic Press, New York and London CERASI, E., and LUFT, R. (1967) Acta endocr. (Kbh.), 55, 278

Collens, w. S., Silverstein, J. N., and dobkin, G. B. (1959) Ann. intern. Med., 50, 1282 Cullen, J. F., TOWN, S. M., and CAMPBell, C. J. (1974) Trans. ophthal. Soc. U.K., 95, 554 DUnCAN, L. J. P., CUllen, J. F., IREland, J. T., NOlan, J., Clarke, B. F., and oliver, M. F. (1968) Diabetes, 17, 458 FAJANS, S. S., and CONN, S. W. (1954) Ibid., 3, 296 fIELd, R. A. (1970) F. Amer. med. Ass., 214, 1126

GOTO, Y., TOYOTA, T., TAKAKU, I., SATO, Y., and IRIE, M. (1970) 'Advances in Metabolic Disorders', suppl. I,

Early Diabetes, ed. R. A. Camerini-Davalos and H. S. Cole, p. 261. Academic Press, New York and London hollenhorst, R. W. (1962) Trans. Amer. Acad. Ophthal. Otolaryng., 66, i 66

JOHANSEN, K. (1969) Amer. F. Med., 47, 487

KORNERUP, T. (1958) Acta ophthal. (Kbh.), 36, 87

LAWRENCE, R. D. (I95I) Proc. roy. Soc. Med., 44, 742

LEVINE, R. (I96I) Surv. Ophthal., 6, 495

LINNER, E., SVANDBORg, A., and Zelander, T. (1965) Amer. F. Med., 39, 298

LUNDBAEK, K. (1955) Acta med. scand., 152, 53

ØSterby, R. (1970) 'Advances in Metabolic Disorders', suppl. I. Early Diabetes, ed. R. A. Camerini-Davalos and

H. S. Cole, p. 26r. Academic Press, London and New York (1972) Diabetologia, 8, 84

PYKE, D. A., and ROBERTS, D. ST. C. (1959) Acta med. scand., 163, 489

SIPERstein, M. D. (I969) 'Pathogenesis of Diabetes Mellitus', ed. E. Cerasi and R. Luft, p. 81. Almqvist and

Wiksell. Förlag AB, Stockholm , norton, w., Unger, r. N., and madison, L. L. (1966) Trans. Ass. Amer. Phycns., 79, 330 , UNGER, R. H., and MADISON, L. L. (1968) $\mathcal{F}$. clin. Invest., 47, 1973

Camerini-Davalos and H. S. Cole, p. 261. Academic Press, New York and London SOELDNER, J. S., SÖNKSEN, P. H., GLEASON, R. E., and BODEN, G. (197I) 'The Action of Hormones, Genes to

Population', eds P. P. Foa, M. L. Foa, and A. J. Whitby, p. 42 I. Thomas, Springfield, Ill.

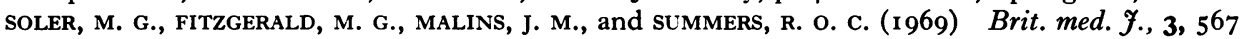

UNGER, R. H., and MADISON, L. L. (1958) $\mathcal{F}$. clin. Invest., 37, 627

WaIte, J. H., and вEATHaM, w. P. (1935) New Engl. F. Med., 212, 367 and 429 